\title{
The Artificial Neural Network Modeling of Language Learning Challenges of French-Speaking Students Learning Turkish as a Foreign Language: The Case of France
}

\author{
Erdogan Kartal ${ }^{1}$ \\ Bursa Uludag University, Turkey
}

\begin{abstract}
This study is about artificial neural network modeling of the linguistic challenges encountered by students learning Turkish as a foreign language in universities in France. The study was conducted in four universities where Turkish is taught as an optional foreign language. Sixty-six students whose mother tongues were either Arabic or French constituted the study group. Planned on a background of an integrated single-case pattern, this study was conducted using a mixed research method which involved gathering and joint interpretation of qualitative and quantitative data groups with an objective to better understand the gaps in knowledge encountered in this research field. The research data were collected through participants' answers to the following open-ended question prepared by the researcher: What are the challenges you encounter when learning Turkish? Data were analyzed using the content analysis method. The results indicated that students find the linguistic elements the most challenging, followed by the aspects of "suffixes," "grammar" and "syntax." In line with these results, an artificial neural network model using the MATLAB computing environment software was created based on the students' mother tongues and linguistic challenges, and the application of this modeling in teaching environments is explained in detail.
\end{abstract}

\section{Keywords}

Turkish as a Foreign Language $\bullet$ Artificial Neural Network Modeling $\bullet$ Language Learning Challenges $\bullet$ French-Speaking Students $\bullet$ MATLAB.

${ }^{1}$ Correspondence to: Erdogan Kartal (PhD), French Language Teaching Department, Faculty of Education, Bursa Uludag University, 16059 Gorukle-Bursa, Turkey. Email: ekartal@uludag.edu.tr

Citation: Kartal, E. (2019). The artificial neural network modeling of language learning challenges of French-speaking students learning Turkish as a foreign language: The case of France. Educational Sciences: Theory \& Practice, 19(1), 55-77. http://dx.doi.org/10.12738/estp.2019.1.0264 
As a result of the fast-paced developments in the area of informatics and communications throughout the second half of the last century, we have stepped into what is commonly defined as the "Informatics" Revolution, following the Agricultural and Industrial revolutions (Kongar, 2002). This process is characterized by rapid transformation in every area of life, especially during the first quarter of the new millennium. A natural consequence of such change and transformation is that modern populations find themselves at the center of a global interaction circle (Göçer \& Moğul, 2011). This interaction brings with it an increase in the scientific, political, artistic, cultural, and commercial relations between populations/countries. This, in turn, makes multilingualism and multiculturalism all the more important in the globalizing world, making the learning of a foreign language necessary, even indispensable. That is why the learning of a/several foreign language(s), which used to be considered a privilege, is now considered a necessity (Kahriman, Dağtaş, Çapoğlu, \& Ateşal, 2013). In addition, along with this process of interaction, the languages and cultures of hegemonic and influential nations have become increasingly significant. Aside from Turkey's indisputable geopolitical and geographical position in the world, social, political, and economic developments recently shaping the world conjuncture, the Middle East in particular, are pushing the country to the forefront of the international scene. Likewise, due to its rich history of several great cultures and civilizations, both past and present, its ever-growing foreign trade volume and its place as one of the most important tourist destinations globally, Turkey holds a privileged position not only among other countries but also, and most importantly, among the neighboring and regional states. Hence, there is an increasing foreign interest in Turkey and a continual growth in the number of Turkish speakers (Özyürek, 2009).

Gaining increasing importance, due to the above-mentioned social and political factors, the Turkish language attracts great interest not merely from those who wish to get to know the country's culture and people better but also from those wishing to establish trade relations with the country, to study or even to live in Turkey, either temporarily or permanently. It is also in high demand in distant regions, where prospective Turkish speakers also have many distinct reasons for learning the language. The main motivations behind foreigners' interest in learning to speak Turkish abroad are academic purposes, commercial activities, diplomatic contacts, cultural interests in the Turks and Turkey, in particular an inclination to become acquainted with an European Union membership candidate, etc. (Erdem, 2009).

Belonging to the Ural-Altaic family of languages, Turkish is one of the world's most widespread languages, with approximately 220 million users (Akar, 2013), used in a vast area ranging from Anatolia to the Balkans (Ercilasun, 2011). According to the United Nations Educational, Scientific and Cultural Organization's (UNESCO) facts, Turkish is the fifth most-spoken modern language in the world (Güzel \& Barın, 2013). Although Turkish is a widespread and significant language, Turkey is the first among countries where Turkish is the native language. Turkey has earned a distinct significance with the ever-growing demand for learning Turkish. We have also witnessed some universities giving impetus to the teaching of Turkish, as the process of teaching Turkish has become increasingly institutionalized, starting from the 1950s onward. Boğaziçi and Ankara Universities are at the forefront of these developments and they have published the very first sources on the teaching of Turkish as a foreign language (Erdem, 2009). From the first half of the 1980s onward, following an initiative for teaching Turkish to foreigners, official Turkish centers (TÖMERs) have been established, inspired by the world's leading language and cultural centers affiliated with major universities worldwide: the British Council (English), Goethe Institute (German), and Instituto Cervantes 
(Spanish) (Ayaz \& Akkaya, 2010). The first TÖMER institute (Turkish and Foreign Languages Application and Research Centre) was established in 1984 as part of Ankara University; its other branches were opened in 1994 as part of Gazi and Ege Universities. Subsequently, with the opening of such institutes within many other public and private universities affiliated with the Council of Higher Education (YÖK), the teaching of Turkish as a foreign language has earned an institutional identity at the higher education level (Bakır, 2014). Today, the teaching of Turkish as a foreign language abroad is conducted in university Turcology departments, Turkish associations, foundations, schools, cultural centers, private courses, and embassies (Arslan, 2012; Dolunay, 2005). As of 2014, Turkey's dialect of the Turkish language was being taught in 80 countries at the secondary education level and in over 60 countries at the higher education level (Arici \& Kaldırım, 2015). The Yunus Emre Foundation, established with public status in 2009, began conducting activities for the teaching of Turkish as a foreign language on behalf of the Turkish Republic through its Yunus Emre Turkish Culture Centers, opened in the four corners of the world. These centers aim to teach Turkish to foreigners in accordance with the Council of Europe's Common European Framework of Reference for Languages (CEFRL) on learning, teaching, and assessment (CEFRL, 2000). In concert with this objective, these centers make improvements to the mode of instruction of Turkish as a foreign language and promote the Turkish language and culture on an international scale (Göçer, Tabak, \& Coşkun, 2012).

Furthermore, the teaching of Turkish as a foreign language is becoming more important with time which has led to the emergence of academic works from the 1990s onward, and, consequently, the number of theses and papers written on the topic has significantly risen (Erdem, 2009). According to Üstünel and Aydın (2009), a reason for this phenomenon is the implementation of the European Language Portfolio in 1998. The introduction of research and regular postgraduate and $\mathrm{PhD}$ programs on the teaching of Turkish as a foreign language in a number of universities in Turkey has also contributed to and supported these academic endeavors. However, as of today, there still is no undergraduate program on the teaching of Turkish as a foreign language in Turkey.

\section{Literature review}

We have observed that the entirety of the academic study pursued on the teaching of Turkish as a foreign language, both in Turkey and around the world, up to the end of 2015, was regularly compiled and consecutively published as "bibliographic studies" (Erdem, 2009; Göçer, Çaylı, \& Çavuş, 2016; Göçer, Tabak, \& Coşkun, 2012; Kahriman et al., 2013). After these bibliographic works and other literature-oriented studies published in 2016 were reviewed (Akkaya \& Gün, 2016; Güler \& Eyüp, 2016; Irmak, 2016; Karataş Demirtaş \& Karataş Acer, 2016; Nurlu \& Özkan, 2016; Yıldız \& Çakır, 2016), we counted 157 scientific studies directly related to the challenges of teaching Turkish as a foreign language in the period from 1983 to 2016. Of these, 70 studies were communiqués, 58 were academic papers, and 29 were postgraduate dissertations. Apart from three pieces of study published in English, all other works in question were published in Turkish, and nearly all of them were conducted by Turkish researchers. As seen in Figure 1, except for certain stagnant years of research (as is the case for 2012), we can see a substantial increase in the number of works published on the challenges of teaching Turkish as a foreign language in recent years. 


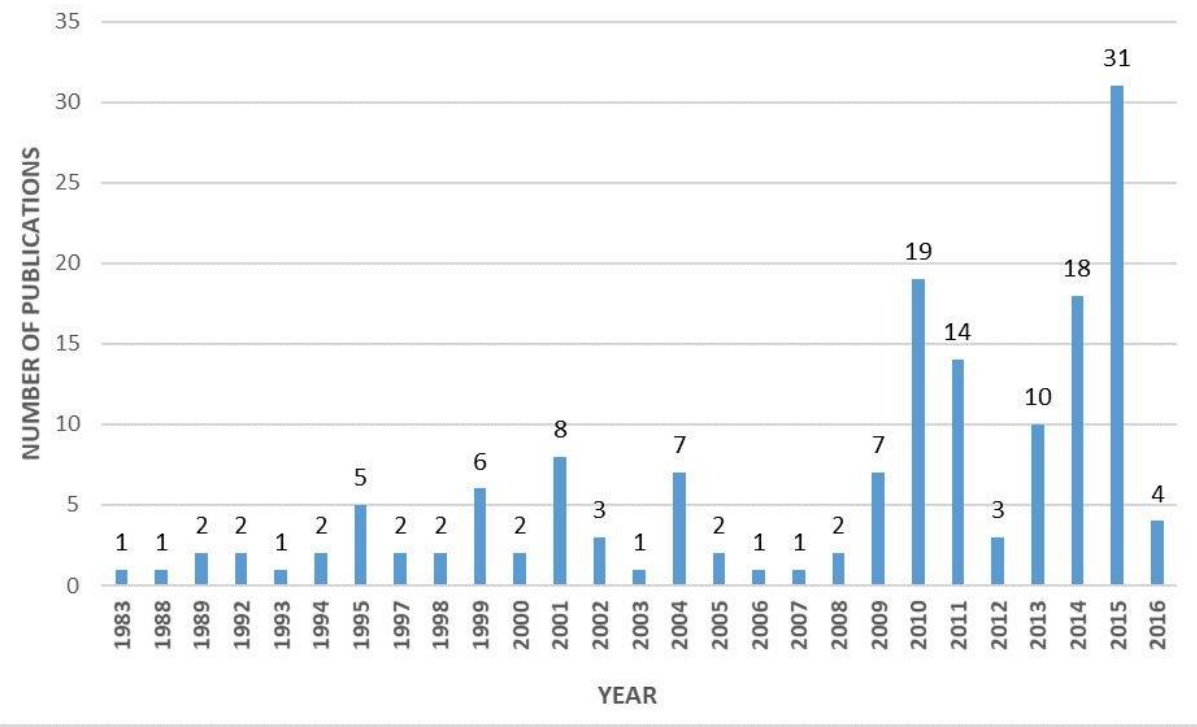

Figure 1. Distribution of academic studies focusing on the challenges of the teaching of Turkish as a foreign language by year.

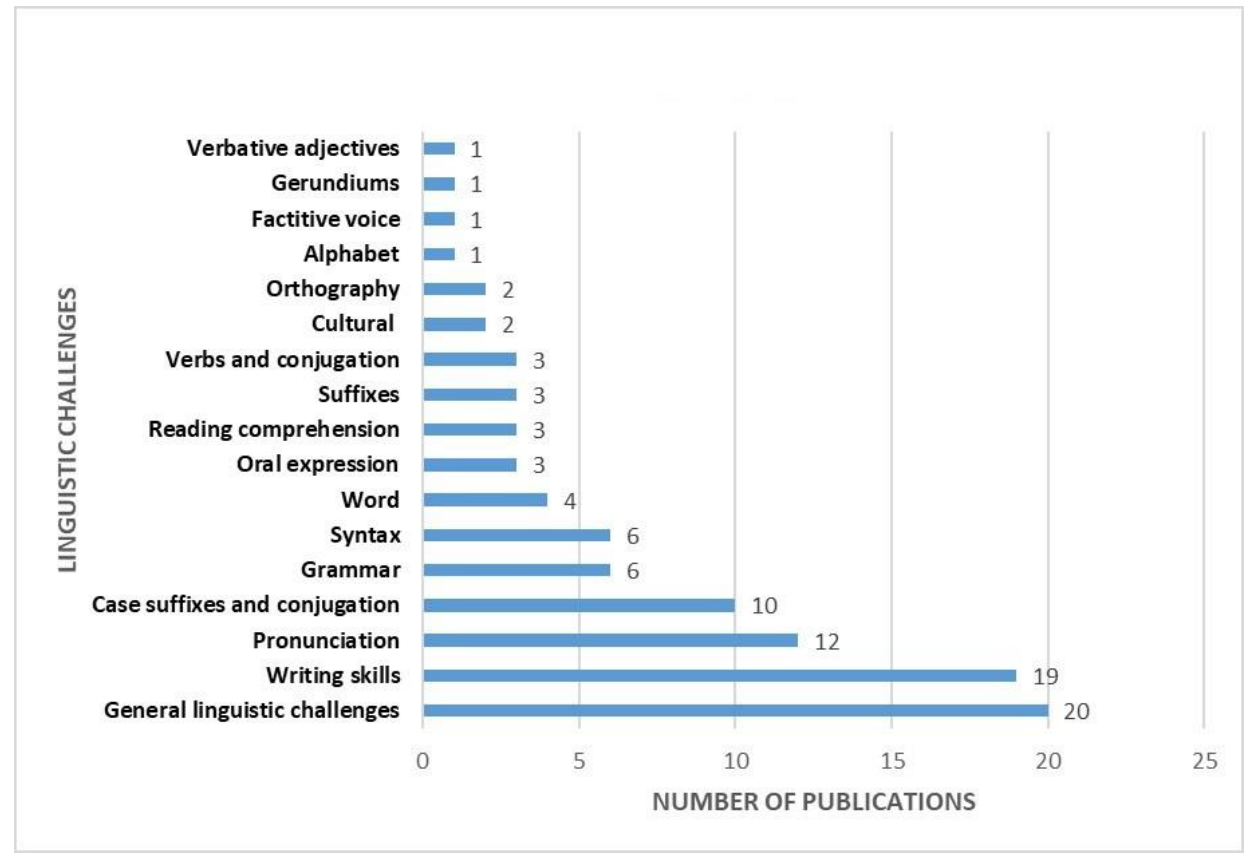

Figure 2. Linguistic subjects treated in academic works focusing on the teaching of Turkish as a foreign language. 
As Kuşçu (2013) notes, these publications classify the challenges under study into the following categories: (1) challenges related to institutionalization; (2) challenges related to the teaching method, curriculum, and teaching materials; and (3) challenges related to the teaching staff.

In addition to the above-mentioned challenges, in nearly two-thirds of these works (97 studies), we note that major linguistic challenges exclusive to the teaching of Turkish as a foreign language, or rather, to the linguistic structure of Turkish are addressed as well (Figure 2). Approximately three-fourths of the studies in this group are focused on pronunciation, grammatical/case suffixes, grammar, and syntax, with an emphasis on the general linguistic challenges of Turkish $(n=20)$ and written expression skills $(n=19)$. The remaining one-fourth of the works focus on more fundamental, specific challenges, such as linguistic skills, words, orthography, alphabet, etc.

Another salient aspect of the studies carried out on the challenges of teaching Turkish as a foreign language is the characteristics of the Turkish-learning student groups upon which these studies were conducted. As shown in Figure 3, half of the studies that constitute the corpus $(n=79)$ were carried out with student groups termed "foreign students" or "foreigners," without any distinction based on nationality or linguistic community. We also observed that the other half of the studies were conducted with groups composed of undergraduate students originating from Turkic countries $(n=21)$, Arab countries $(n=12)$, Russia $(n=7)$, Albania $(n=5)$, Germany $(n=5)$, far-Eastern countries $(n=4)$, Bosnia $(n=4)$, etc.

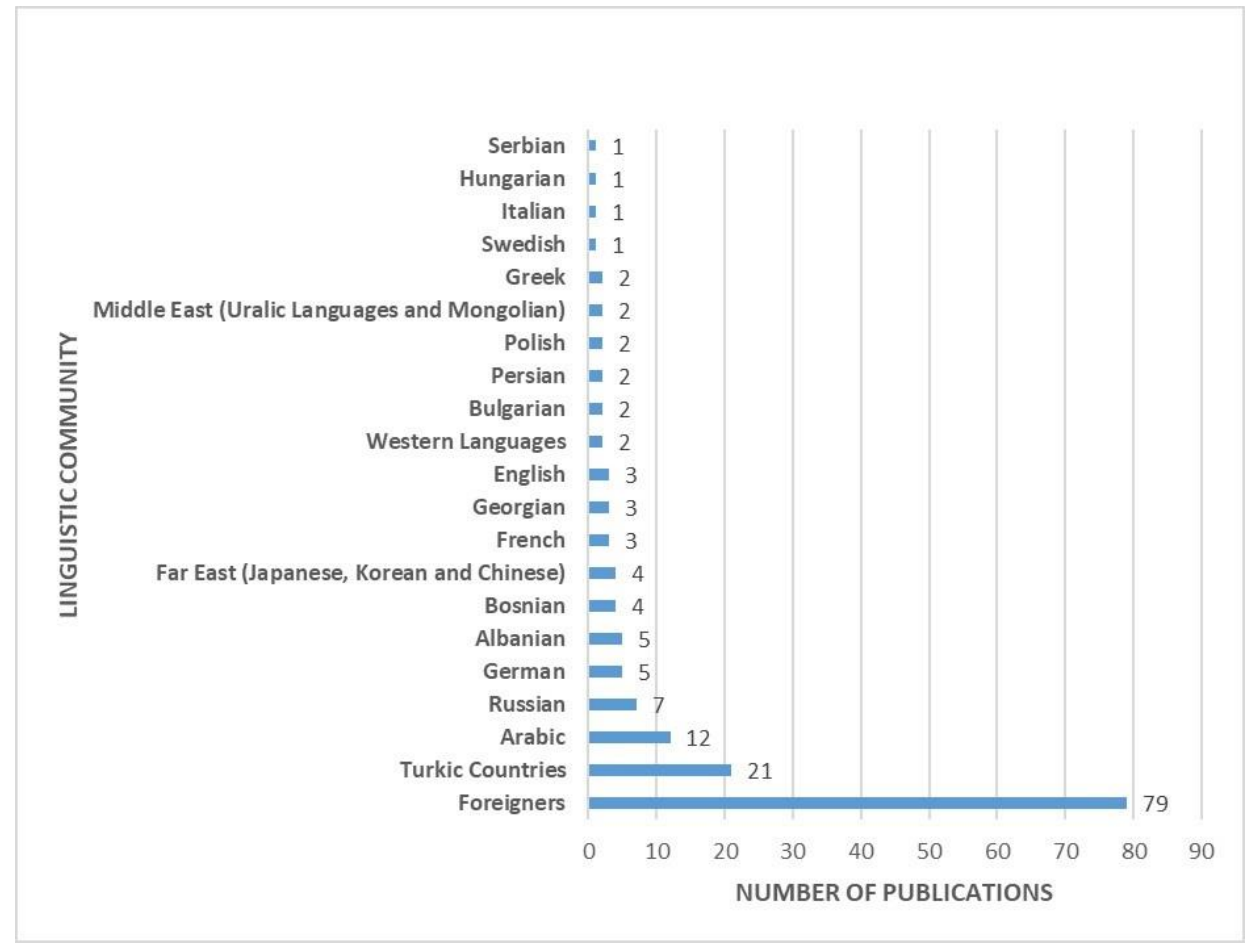

Figure 3. Distribution of academic studies focusing on the challenges of teaching Turkish as a foreign language based on the linguistic community of the students. 
Lastly, when we reviewed the literature on the challenges and difficulties of teaching Turkish as a foreign language, we found only three studies that focused on French-speaking students learning Turkish at the higher education level (Figure 3). All of these were communiqués (Çiçek, 2010; Ozdemir, 2004): two of them are fully published, and the third is only available as an abstract. After an analysis of the three works, we came to the conclusion that, as is the case with the majority of studies constituting the literature, these works too are based only on the observations of teachers teaching Turkish to foreigners only. In this context, the present study attempts to fill a gap in the literature by discussing the possible linguistic challenges encountered by French-speaking students while learning Turkish as a foreign language.

\section{Significance of the study}

As with all other disciplines, language teaching is adopting an eclectic approach (Puren, 1988), diversifying and improving its method/approach, teaching setting, and materials according to scientific research results. As such, the teaching of Turkish must also be carried out in accordance with modern teaching methods/approaches based on scientific research. Nevertheless, Göçer, Tabak, and Coşkun (2012) argue that, despite the high number of academic works produced on the teaching of Turkish as a foreign language, those works are unsatisfactory in meeting today's fluctuating demands.

Moreover, the study conducted by Biçer, Çoban, and Bakır (2014) on the challenges encountered by foreign students learning Turkish at Atatürk University ascertains that the Turkish-learning programs for foreigners do not take the learners' mother tongue, age, education level, and culture into account and that the applied methods and materials used in the teaching of Turkish as part of the program are not in sync with the present-day context. Therefore, considering scientific research results and student feedback is of utmost importance in producing works related to the teaching of Turkish as a foreign language and in the subsequent development of teaching materials.

\section{Purpose of the study}

In this study, we aim to establish an artificial neural network model of the challenges encountered by French-speaking students learning Turkish as a foreign language in universities in France. With this network, this study determines the challenging areas pertaining to the idiosyncratic characteristics of Turkish and grammar aspects encountered by French-speaking students while learning Turkish as a foreign language and proposes homogenous grouping to address these challenges.

\section{Method}

In this study, a mixed research method was used to establish an artificial neural model of the linguistic challenges pertaining to Turkish as perceived by French-speaking students learning Turkish. According to 
Creswell (2014), mixed method research studies involve gathering of qualitative and quantitative data and the joint interpretation of the two data groups with the aim of understanding the gaps in knowledge of the research field.

In the qualitative dimension of this research, where a mixed method was adopted, the case-study method, a frequently used qualitative research method, was used, which allows for an in-depth analysis of any given fact in its own natural environment. In addition, as this work was carried out on only French-speaking students learning Turkish as a foreign language, it constitutes an integrated single-case pattern as it contains only one analysis unit. Integrated single-case patterns are used when dealing with out-of-standard, idiosyncratic cases, or in cases that have not been treated or could not be approached previously (Yıldırım \& Şimşek, 2011).

As for the quantitative dimension of the study, the data gathered through interviewing students based on a question-answer approach were analyzed using the content analysis method and converted to numeric values. Then, these numeric values were used to create a model with artificial neural networks using the multiparadigm numerical computing environment software MATLAB (Matrix Laboratory).

The limitations of the present study are that the research scope is restricted to Francophone students from various language groups, and other linguistic variables do not figure within the scope of the study, such as reasons as to why they learn, languages they speak, their foreign language proficiency levels, programs they are in, attitudes they have towards language learning, etc.

\section{Participants}

As of the 2016-2017 academic year, six higher education institutions in France were involved in teaching Turkish as a foreign language: five universities and one institute. Two of these higher educational institutions are the National Institute for Oriental Languages and Civilizations-(INALCO) in Paris, teaching at the undergraduate and postgraduate levels, and Strasbourg University's Department of Turkish Studies. In AixMarseille, Saint-Étienne, Bordeaux Montaigne, and Lyon 2-Lumière Universities, Turkish is taught as an optional (elective) course as part of Literature, Languages and Civilizations Faculties and the Modern Languages Departments.

In France, aside from higher educational institutions, which have chairs for Turkish language, Turkish courses are offered by Turkish lecturers appointed to the Education Attaché's Office of the Turkish General Consulate in Lyon after being selected through tests administered by the External Relations General Directorate of the Turkish Republic Ministry for Education.

The students of the National Institute for Oriental Languages and Civilisations (INALCO) in Paris and the University of Strasbourg graduate as Turcologists after completing their undergraduate and postgraduate programs within these institutions, which is why they have not been included in the population of the study. We adopted the convenience sampling method. In this framework, 66 volunteers, out of the 99 students who were studying at different undergraduate and postgraduate language and literature programs and learning Turkish as an optional foreign language course in the other four universities during the 2016-2017 academic 
year, constitute the work's study group. The data for students studying in these programs and participating in the current study are given in Table 1.

Table 1. Numbers, institutions and mother-tongue data pertaining to the students participating in the study.

\begin{tabular}{|c|c|c|c|c|c|c|c|c|}
\hline \multirow[b]{2}{*}{ University } & \multirow[b]{2}{*}{ 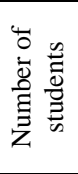 } & \multirow[b]{2}{*}{ 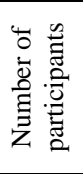 } & \multicolumn{6}{|c|}{ Mother tongue } \\
\hline & & & $\frac{\frac{0}{\pi}}{\frac{\pi}{2}}$ & 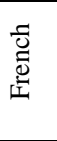 & $\underset{\vec{\Delta}}{\stackrel{N}{\Delta}}$ & 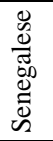 & 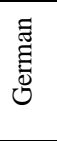 & 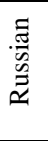 \\
\hline Saint-Étienne & 4 & 4 & 1 & 3 & - & - & - & - \\
\hline Lyon 2-Lumière & 14 & 9 & 9 & - & - & - & - & - \\
\hline Bordeaux 3-Montaigne & 35 & 29 & 8 & 18 & 1 & & 2 & - \\
\hline Aix-Marseille & 42 & 24 & 17 & 5 & - & 1 & - & 1 \\
\hline Total & 95 & 66 & 35 & 26 & 1 & 1 & 2 & 1 \\
\hline
\end{tabular}

As gender and ethnic origin of students had no relevance to the study's objective and content, they were not investigated during data collection. However, students were asked what their mother tongues were and for how long they had been learning Turkish. As seen in Table 1, the mother tongue of slightly more than half of the participants is Arabic, and nearly one-third speak French as their mother tongue. Based on the researcher's observations for around 2 years, it was possible to ascertain that nearly all the students whose mother tongue is Arabic are Maghrebians (i.e., people of Moroccan, Algerian, or Tunisian descent), that is, Franco-Arabic. For the latter and Senegalese students, French is a second language (thus making them bilingual) due to historical and cultural processes, whereas for the other four categories of students whose mother tongues are different (two Germans, one Kyrgyz, and one Russian), French is a completely foreign language. All the students were proficient in French as they are in France to study at university.

As part of the programs of the universities in this study, Turkish is taught for 2 hours a week as an optional (or elective) course. Considering the weekly curricular length and duration of students' attendance in the course, participants are at the beginner level of speaking Turkish.

\section{Instruments}

In this study, an open-ended question was asked to French students as the data collection tool. Aiming at the written expression of the challenges they encounter during the learning of Turkish as a foreign language, they were asked What are the linguistic challenges you encounter when learning Turkish? Please specify in detail. Brew (2008) argues that open-ended questions can reflect the participants' perspectives in detail because they allow the respondents to express themselves freely. The question was presented to students in the form of a questionnaire in French that contained their mother tongue and university information as well.

\section{Design and procedure}

As indicated above, as Turkish lecturers appointed by the Turkish Ministry of Education and affiliated with the Education Attaché's Office of the Turkish Consulate General in Lyon are working in French universities where Turkish is taught as a foreign language, we first contacted the Education Attaché's Office, gave information on the study, and obtained the necessary authorization for collecting the data. At the beginning of the Spring term of the 2016-2017 academic year, the questionnaire was transmitted to lecturers via the Attaché's Office, which in turn contacted their academic administrations to get permission to conduct 
the survey, and they informed their students of the study at the beginning of the term. The study was carried out with volunteer students among those who attended class on the last week of the Spring term. Sufficient time was given to students to answer the question. The questionnaires with student responses were delivered to the researcher by post.

\section{Data analysis}

The data collected as part of the study were analyzed using the content analysis method. According to Büyüköztürk, Çakmak, Akgün, Karadeniz, and Demirel (2012), content analysis consists of a systematic, renewable technique where certain words of a text are summarized into their smaller subcategories following coding based on specific rules. The questionnaires were first classified according to the universities where the students were studying, and then each was enumerated with the initials of the universities: LL1 and AM66. The responses of students who expressed the linguistic challenges they perceived in the learning of Turkish in written form were scrutinized by the researcher and an expert in the field, leading to an agreement on what the codes - in other words, linguistic challenges - were and which terms had to be used to code them. Then, both researchers categorized participants' answers to the open-ended question based on the agreed-upon codes. We calculated the compatibility percentage between encoders with the below-given formula (Miles \& Huberman, 1994) as $93 \%$.

Compatibility percentage between encoders $=100 \times$

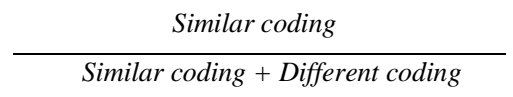

Data collected in this context were presented as they were, without any interpretation. Furthermore, the entire data collected during the study were archived in case other researchers wished to refer to them in the future.

\section{Results and discussion}

In this section, we present the findings from the research data after content analysis, along with our interpretations of these findings within the framework of the current literature.

\section{Linguistic challenges encountered by students when learning Turkish}

Table 2. Linguistic challenges encountered by students while learning Turkish.

\begin{tabular}{|c|c|c|c|c|c|c|c|c|}
\hline Linguistic challenges & 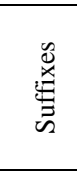 & 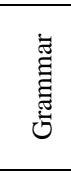 & 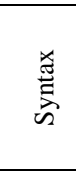 & 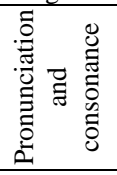 & 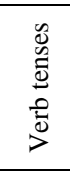 & $\begin{array}{l}\overrightarrow{0} \\
\dot{0}\end{array}$ & 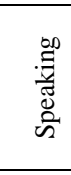 & 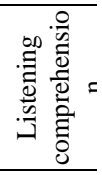 \\
\hline Number & 26 & 26 & 22 & 14 & 13 & 11 & 11 & 3 \\
\hline Percentage & 39.4 & 39.4 & 33.3 & 21.2 & 19.8 & 16.7 & 16.7 & 4.5 \\
\hline
\end{tabular}


"syntax," with rates nearing 40\%. The second group comprises "pronunciation and consonance," "verb tenses," "words" and "speaking," which are defined as challenges by nearly one-fifth of the participating students.

As for the nature of the linguistic challenges stated by students, we noticed that nearly $90 \%$ of them are related to grammar, morphology, syntax, vocabulary, and pronunciation, which are defined as "components of language" in CEFRL (2000). Very few of these challenges (approximately 10\%) are directly related to fundamental language skills such as "speaking" and "listening comprehension." This phenomenon can be explained by the fact that Turkish is, for all participants, a second or even third optional course and has a limited weekly curriculum (on average, 2 hours per week). As students are at the beginner level, courses are more focused on grammar than on fundamental linguistic skills such as reading, writing, speaking, and listening comprehension. That is why, at this level, students expressed very few challenges related to fundamental language skills. Moreover, this finding also aligns with the objective specified in the legislation (http://abdigm.meb.gov.tr/yurtdisiteskilati/) of the only official authority as regards the courses and curricula to be taught in these departments, the Turkish Ministry of Education, Directorate General for European Union and External Relations. Accordingly, the objective in question is the "Promotion, dissemination, and preservation of Turkish language and culture abroad."

\section{Averages of linguistic challenges according to students' mother tongues}

Among students participating in the study, those whose mother tongues were German $(n=2)$, Kyrgyz, Russian, and Senegalese were very few in number (Table 1) and thus could not be considered as samples for their respective languages. The averages of their linguistic challenges according to subjects covered during Turkish instruction were not included in the analysis.

Table 3. Averages of students' linguistic challenges according to their mother tongues.

\begin{tabular}{|c|c|c|c|c|c|c|c|c|}
\hline $\begin{array}{l}\text { Linguistic } \\
\text { ckallenges } \\
\text { Mother } \\
\text { tongue }\end{array}$ & $\underset{\tilde{u}}{\stackrel{\tilde{x}}{E}}$ & 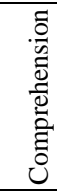 & 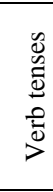 & $\begin{array}{l}\tilde{0} \\
\dot{0} \\
3\end{array}$ & 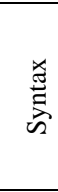 & 芯 & 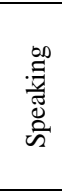 & 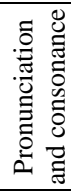 \\
\hline & $\mathrm{M}$ & $\mathrm{M}$ & $\mathrm{M}$ & $\mathrm{M}$ & $\mathrm{M}$ & $\mathrm{M}$ & $\mathrm{M}$ & $\mathrm{M}$ \\
\hline Arabic (35 students) & 0.4 & 0.1 & 0.2 & 0.1 & 0.3 & 0.5 & 0.2 & 0.2 \\
\hline French (26 students) & 0.5 & 0 & 0.2 & 0.3 & 0.5 & 0.3 & 0.2 & 0.2 \\
\hline
\end{tabular}

Table 3 gives the averages of linguistic challenges according to the learning subjects of the participants of two study groups whose mother tongues were different (Arabic and French). A closer look at those averages reveals that the groups' linguistic challenge averages are very close to each other, which may be due to French being the second language (at the bilingual level) of Arabic students of Maghrebin origin. The students in question have, in a manner of speaking, adopted French as a second mother tongue, since they were born, raised, and taught in environments where it was spoken (Philip-Asdih, 1997). Therefore, it is possible to state that these two study groups form a single homogenous group based on their mother tongue. Another common aspect of the two groups is that although they belong to different language families (Figure 1), and they are 
very distinct as regards their alphabets and pronunciation (Philip-Asdih, 1997), these languages belong to the same language subgroup due to their structure (morphology) as "inflected languages" (having words whose stem changes during conjugation) (Baccouche, 2009; Ravel, 2013).

\section{Modeling and applications}

Artificial neural networks were introduced to the scientific world in the 1940s. At present, research shows that by bringing various cells together using suitable learning algorithms, neural networks can be established to achieve complicated missions (Ataseven, 2013). Artificial neural networks, which have a similar infrastructure to the brain, have a capacity to learn what has been set up in the computed environment (Kutlu \& Badur, 2009). An artificial neural network that has been inspired by the biological neurons (Ataseven, 2013) is a non-linear, complicated, and flexible mathematical structure that is between the sets of inputs and outputs (Hsu, Gupta, \& Sorooshian, 1995; Pavlin-Bernardić, Ravić, \& Matić, 2016). It is also pointed out that this structure can change the result in line with the non-linear and parallel data processing, tolerate minor changes in the input parameters, and respond to new data (Ataseven, 2013).

Used mainly in the fields of engineering and medicine, this field of science is also frequently utilized in various domains such as optimization, classification, and prognosis (Vatansever \& Doğalı, 2011). Even though neural networks are highly useful in terms of estimating and categorizing multiple variables, in the field of education their use is still very rare (Pavlin-Bernardić et al., 2016; Xu \& Rudnicky, 2000). Therefore, an artificial neural network is a new methodological approach to learning and teaching. Although an artificial neural network is effective in terms of identifying models of relations and maximizing the forecasting ability of variables (Musso, Kyndt, Cascallar, \& Dochy, 2013), the cost of calculation is higher than other standard methods (Xu \& Rudnicky, 2000). Studies like Xu and Rudnicky (2000) indicate that even though artificial neural networks have become popular, it is rare to encounter this methodological approach in studies on modeling languages. In addition, according to the study in question, neural networks are able to learn a language model at an even better level when compared to standard statistical methods.

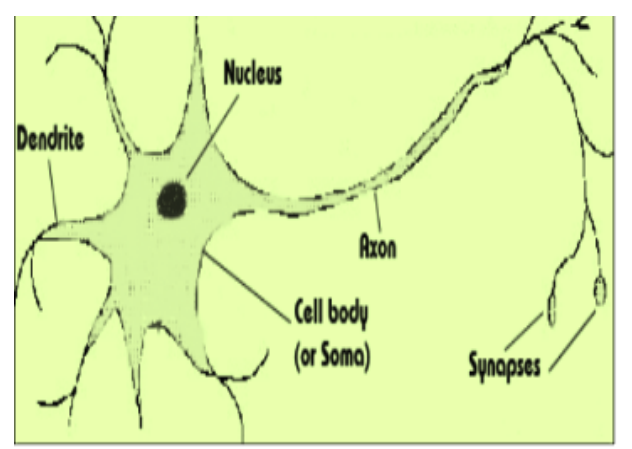

Figure 1a

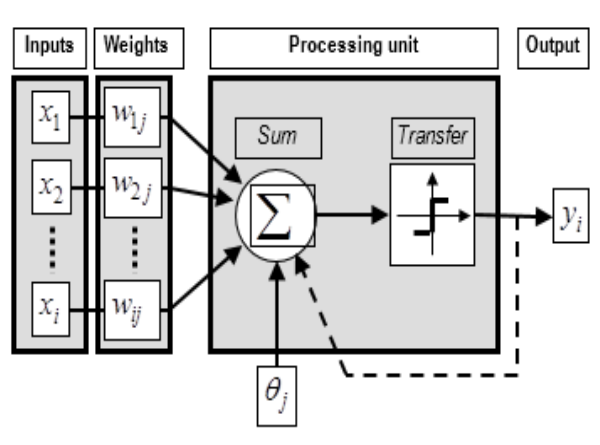

Figure 1b

Figure 4. (a) Biological and (b) artificial neural structures.

In this part of the study, the findings drawn from content analysis, which were converted into numerical values according to student groups, mother tongues, and linguistic challenges, were put into a matrix and 
modeled with an artificial neural network in student groups using the multi-paradigm numerical computing environment software MATLAB (Matrix Laboratory). The artificial neural network modeling was used for pattern recognition. Then, we explain how this modeling can be put into practice and offer benefits to future research and instruction. The artificial neural structure developed on the basis of the biological neural structure (Figure 4a) is given in its most general form in Figure 4b. The comparison of biological and artificial neural structures is given in Table 4 (Vatansever \& Doğalı, 2011).

Table 4. Comparison of biological and artificial neural structures.

\begin{tabular}{ll}
\hline Biological neural system & \multicolumn{1}{c}{ Artificial neural system } \\
\hline Neuron & Processing unit \\
Synapse & Weight \\
Dendrite & Sum function \\
Cell body (soma) & Transfer/activation function \\
Axone & Output \\
\hline
\end{tabular}

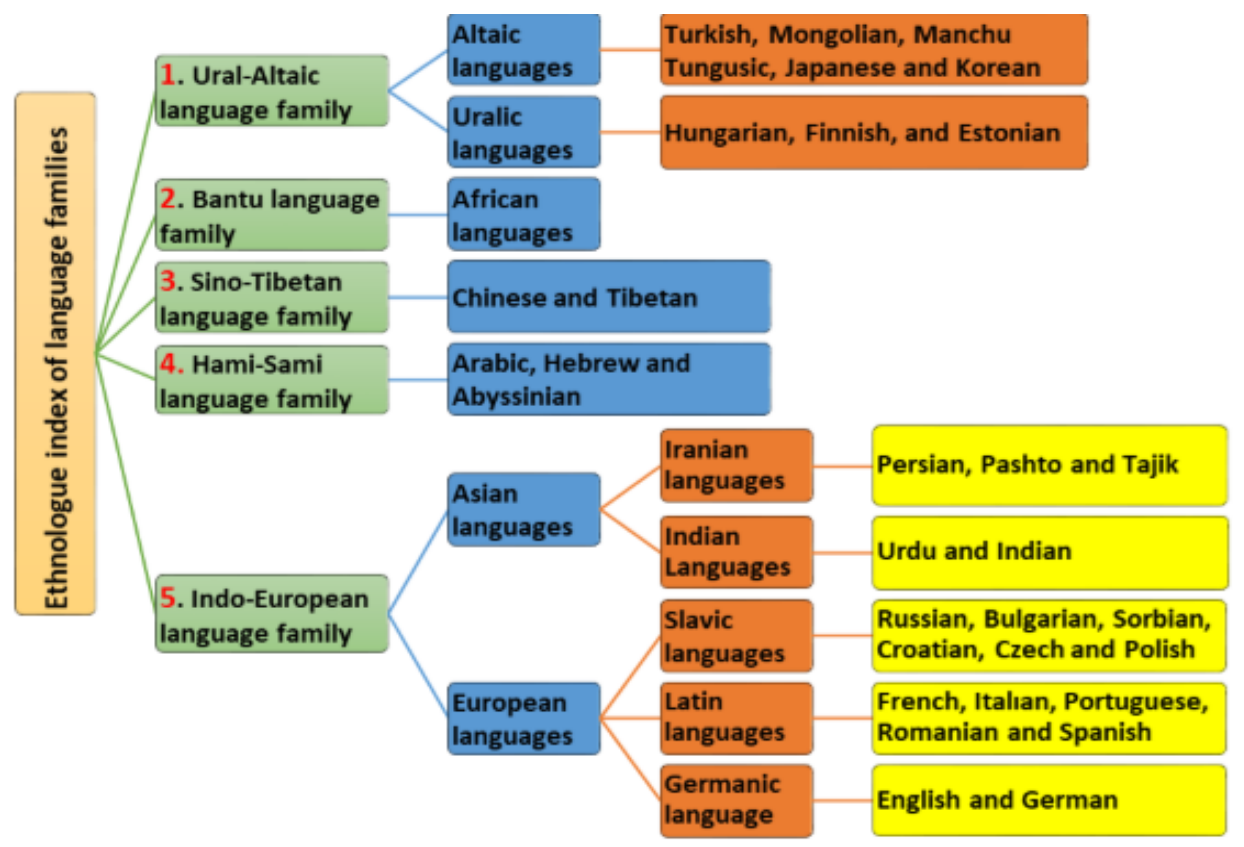

Figure 5. Families of languages based on their etymons.

\section{Entry matrix: Conversion of students' mother tongues into numerical values}

Linguists have identified 3,000 different languages globally (Jean, 1987). All of these languages are generally divided into two groups based on their etymon and structure. Those that are similar in terms of their etymon form a language family. As such, world languages are divided into several language families. A language family is defined as a community of languages formed by languages generated at a point in time 
from one common mother tongue. Following Kapusuzoğlu (2010), similarities existing between languages pertaining to the same language family fortify this assumption. As shown in Figure 2, and as featured on the Turkish Language and Literature Association's website (https://www.turkedebiyati.org/turk_dili/dillerin_siniflandirilmasi.html), all modern world languages can be classified into five main families of languages based on their etymons.

According to Table 1, which shows the number of participating students and their mother tongues, the mother tongues of the students were as follows: Arabic (35); French (26); German (two); and one each for Kyrgyz, Senegalese, and Russian. Research on the language families of Kyrgyz and Senegalese is found in Ethnologue: Languages of the World (https://www.ethnologue.com), the official website of The Summer Institute of Linguistics (SIL) organization. Kyrgyz belongs to the Altaic languages stream of the Ural-Altaic family of languages, just as Turkish does. In the case of Senegal, although the official language is French, people speak many other local languages - Bambara is the most widespread of all, and it belongs to the Bantu family of languages.

For practical purposes, the mother tongues of students learning Turkish were classified according to their resemblance to Turkish on the basis of their etymon (Figure 5). When this convergence was converted into a mathematical expression, it was transformed into an entry matrix that was related to the target matrix. Thus, artificial neural networks could be trained based on these values.

Let us take $(1 / 2)^{\wedge}(n-1)$ as the convergence of all languages and $n$ as the number of the language families diverging from Turkish. Accordingly, Kyrgyz, which, like Turkish, belongs to the first family of languages, was given the value 1; Senegalese (Bambara), which belongs to the second family of African languages, was given the value of $1 / 2$ (0.50); Arabic, belonging to the fourth family of languages, was given the value of $1 / 4$ (0.25); and, lastly, French, German, and Russian, belonging to the fifth family of languages, were given the numerical value $1 / 5(0.20)$. In this way, the numerical values obtained through that formula are presented in Table 5, where a matrix for the linguistic challenges foreseen by students learning Turkish is shown.

The Entry Matrix created with each challenge coefficient assigned to each student in accordance with their mother tongue could, first and foremost, be used in the constitution of homogenous language classes. For example, students whose mother tongue challenge coefficients are similar or close could be gathered in the same classroom. With such an arrangement, both locally and globally, situations such as having students with different mother tongues (i.e., Arabic and Japanese) in the same classroom when teaching them Turkish at the beginner level, both at home and abroad, could be avoided. As stated by Durmuş (2013), the more homogenous classes are, the more successful teaching activities are.

Taking the mother tongue of the majority of students in these classes into consideration, local teachers, who would be fluent in the native language of those students (who are able to work in the Native Turkish language group), could be assigned to these classes. Thus, these teachers could put forth similarities and contrasts between the student groups' mother tongues and Turkish by using the "differential analysis" method. The latter is defined as an efficient tool in foreign language teaching and is based on fundamental structural linguistics (Fries, 1945, cited by Aydın, 2010). The similarities and contrasts can be sorted out according to 
linguistic challenge degrees and used as guidelines in the setting of course hours, teaching approaches, and materials (Dede, 1983).

\section{Target matrix: Linguistic challenges of Turkish as stated by students}

The target matrix was created based on each of the linguistic challenge subjects stated by students. In subjects where students encountered challenges, a numerical value was attributed to each column in a table. These numerical values were 1 for challenge areas, and 0 for other areas.

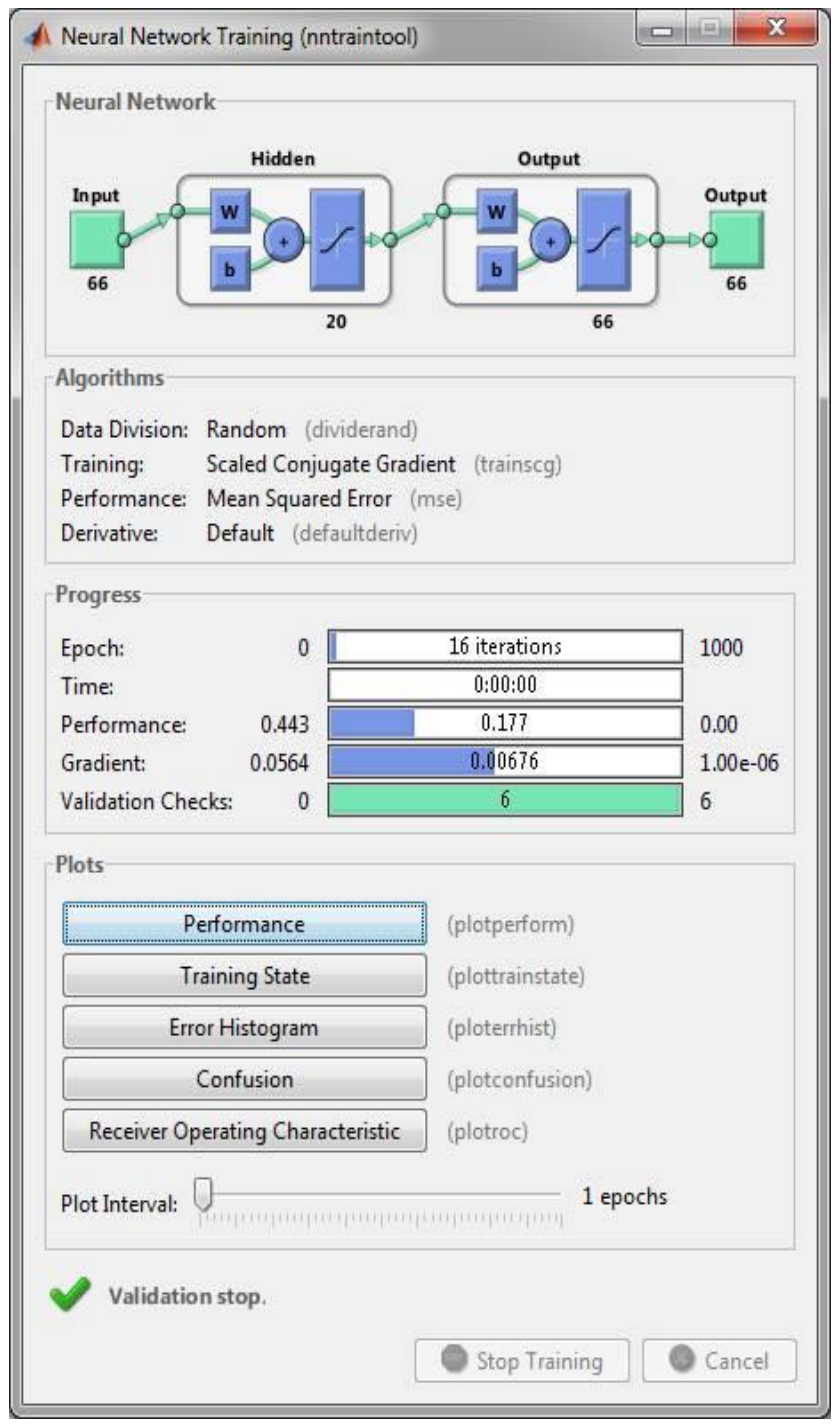



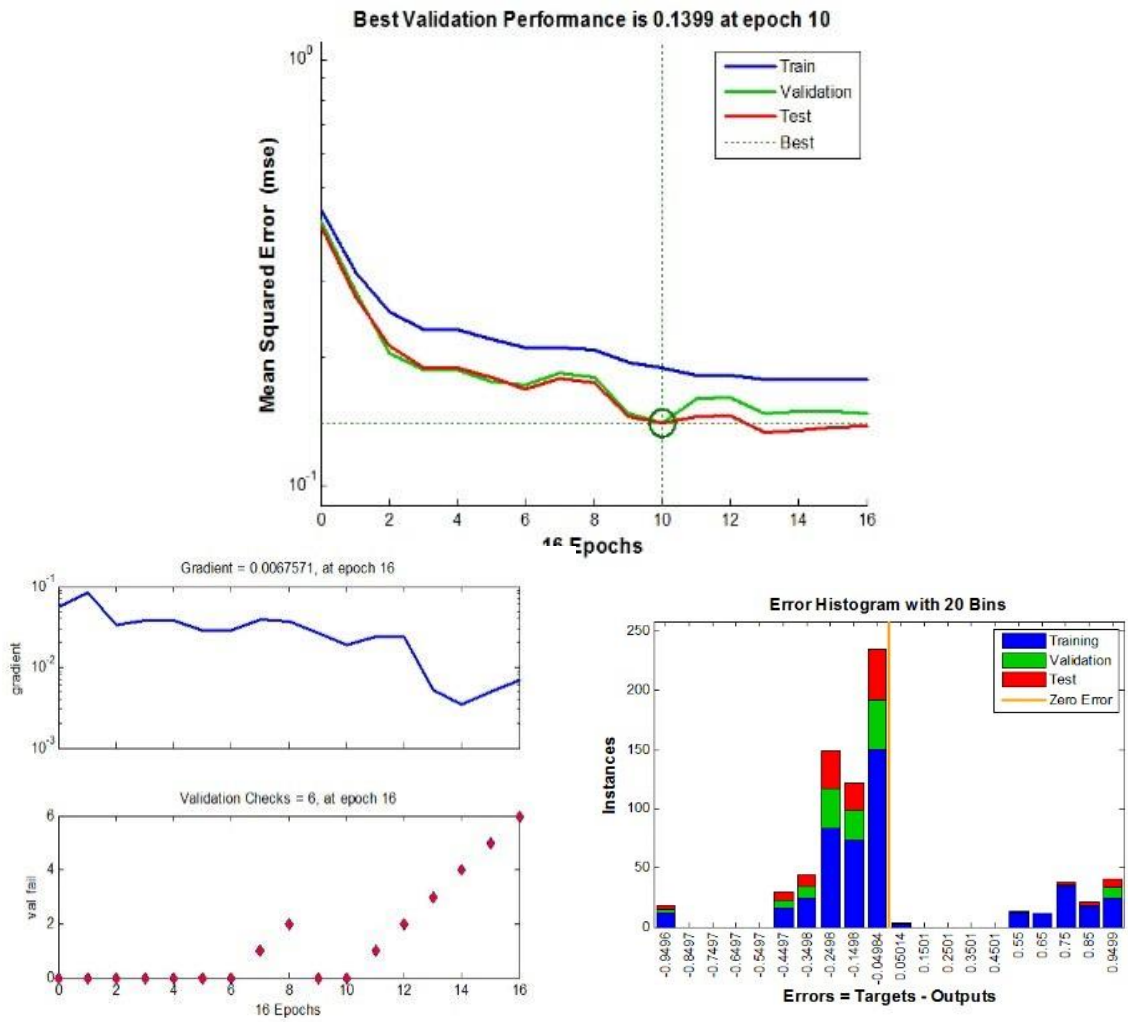

Figure 6. Examples of application results of the model.

The MATLAB software with an ANN Toolbox was required to put the above-stated computation into practice. The prepared data were inserted into the MATLAB command window using the load command. With these data, the student variable was used as the entry value and expressed the students' numerical values, whereas the target variable pointed to - as explained previously - the areas of challenge and constituted the target matrix of the artificial neural network. The mathematical expression of the entry matrix composed of students will be given in the next section. After the data were inserted, the interface software of ANN Toolbox was opened via insertion of the nnstart command. Then, the Pattern Recognition App was selected to launch the pattern recognition application, and the input and target variables were presented to the software in the following windows. Students had to be identified as the input variable, while linguistic challenges were identified as the target variable. Afterward, directives could be used for the system's success and to reach other results from it (Figure 6).

As an example, we see numerically that student no. 17 (BM4) in Table 5 encountered challenges in "verb tenses" and "words." The difficulties experienced by the rest of the students could also be assessed this way. 
Table 5. Matrix of linguistic challenges of Turkish as foreseen by students.

\begin{tabular}{|c|c|c|c|c|c|c|c|c|c|c|c|}
\hline$\dot{\mathbf{Z}}$ & 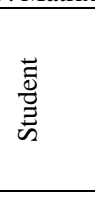 & 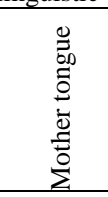 & 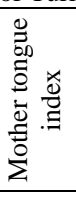 & 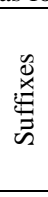 & 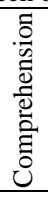 & 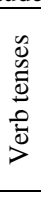 & $\frac{a}{0}$ & 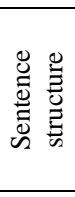 & 苂 & 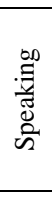 & 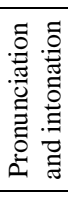 \\
\hline 1 & SE1 & French & 0.20 & 1 & 0 & 0 & 0 & 0 & 0 & 0 & 0 \\
\hline 2 & $S E 2$ & Arabic & 0.25 & 1 & 0 & 0 & 0 & 0 & 0 & 0 & 0 \\
\hline 3 & SE3 & French & 0.20 & 0 & 0 & 0 & 0 & 1 & 0 & 0 & 0 \\
\hline 4 & SE4 & French & 0.20 & 0 & 0 & 0 & 1 & 0 & 0 & 0 & 0 \\
\hline 5 & LL1 & Arabic & 0.25 & 0 & 0 & 0 & 0 & 1 & 1 & 0 & 0 \\
\hline 6 & $L L 2$ & Arabic & 0.25 & 0 & 0 & 0 & 0 & 0 & 0 & 1 & 0 \\
\hline 7 & LL3 & Arabic & 0.25 & 1 & 0 & 0 & 0 & 1 & 0 & 0 & 0 \\
\hline 8 & LL4 & Arabic & 0.25 & 1 & 0 & 0 & 0 & 1 & 0 & 0 & 1 \\
\hline 9 & LL5 & Arabic & 0.25 & 1 & 0 & 0 & 1 & 0 & 0 & 0 & 1 \\
\hline 10 & LL6 & Arabic & 0.25 & 1 & 0 & 0 & 0 & 0 & 0 & 0 & 0 \\
\hline 11 & LL7 & Arabic & 0.25 & 1 & 0 & 0 & 0 & 0 & 0 & 0 & 1 \\
\hline 12 & $L L 8$ & Arabic & 0.25 & 1 & 0 & 0 & 0 & 0 & 0 & 0 & 1 \\
\hline 13 & LL9 & Arabic & 0.25 & 0 & 0 & 0 & 0 & 0 & 0 & 0 & 1 \\
\hline 14 & $B M 1$ & French & 0.20 & 0 & 0 & 1 & 1 & 1 & 0 & 0 & 1 \\
\hline 15 & $B M 2$ & French & 0.20 & 0 & 0 & 1 & 0 & 1 & 0 & 0 & 1 \\
\hline 16 & BM3 & German & 0.20 & 0 & 0 & 1 & 0 & 0 & 0 & 0 & 1 \\
\hline 17 & BM4 & French & 0.20 & 0 & 0 & 1 & 1 & 0 & 0 & 0 & 0 \\
\hline 18 & BM5 & Kyrgyz & 1 & 0 & 0 & 0 & 1 & 0 & 0 & 0 & 0 \\
\hline 19 & BM6 & French & 0.20 & 1 & 0 & 0 & 0 & 1 & 0 & 0 & 0 \\
\hline 20 & $B M 7$ & Arabic & 0.25 & 0 & 0 & 0 & 0 & 0 & 1 & 1 & 0 \\
\hline 21 & BM8 & Arabic & 0.25 & 0 & 0 & 1 & 1 & 0 & 0 & 0 & 0 \\
\hline 22 & BM9 & Arabic & 0.25 & 1 & 0 & 0 & 0 & 0 & 0 & 0 & 0 \\
\hline 23 & BM10 & French & 0.20 & 0 & 0 & 0 & 1 & 1 & 1 & 0 & 0 \\
\hline 24 & BM11 & French & 0.20 & 1 & 0 & 0 & 0 & 0 & 1 & 0 & 0 \\
\hline 25 & BM12 & French & 0.20 & 1 & 0 & 0 & 1 & 0 & 0 & 0 & 1 \\
\hline 26 & BM13 & French & 0.20 & 0 & 0 & 0 & 0 & 1 & 0 & 0 & 0 \\
\hline 27 & BM14 & Arabic & 0.25 & 0 & 0 & 1 & 0 & 0 & 1 & 0 & 0 \\
\hline 28 & BM15 & Arabic & 0.25 & 0 & 0 & 1 & 0 & 0 & 1 & 0 & 0 \\
\hline 29 & BM16 & Arabic & 0.25 & 1 & 0 & 0 & 0 & 0 & 1 & 0 & 0 \\
\hline 30 & $B M 17$ & French & 0.20 & 0 & 0 & 0 & 1 & 0 & 1 & 0 & 0 \\
\hline 31 & BM18 & Arabic & 0.25 & 0 & 0 & 0 & 0 & 1 & 1 & 0 & 0 \\
\hline 32 & BM19 & French & 0.20 & 1 & 0 & 0 & 0 & 0 & 0 & 1 & 0 \\
\hline 33 & BM20 & German & 0.20 & 0 & 0 & 0 & 0 & 1 & 0 & 0 & 0 \\
\hline 34 & $B M 21$ & French & 0.20 & 1 & 0 & 0 & 0 & 0 & 0 & 1 & 0 \\
\hline 35 & $B M 22$ & French & 0.20 & 1 & 0 & 0 & 0 & 0 & 0 & 0 & 1 \\
\hline 36 & $B M 23$ & French & 0.20 & 1 & 0 & 0 & 0 & 1 & 0 & 0 & 0 \\
\hline 37 & $B M 24$ & French & 0.20 & 1 & 0 & 0 & 0 & 0 & 0 & 0 & 0 \\
\hline 38 & $B M 25$ & Arabic & 0.25 & 0 & 0 & 0 & 0 & 1 & 1 & 0 & 0 \\
\hline 39 & BM26 & French & 0.20 & 1 & 0 & 0 & 0 & 1 & 1 & 0 & 0 \\
\hline 40 & $B M 27$ & French & 0.20 & 1 & 0 & 0 & 0 & 1 & 0 & 1 & 0 \\
\hline 41 & BM28 & French & 0.20 & 0 & 0 & 0 & 0 & 0 & 0 & 1 & 0 \\
\hline 42 & BM29 & French & 0.20 & 0 & 0 & 0 & 1 & 0 & 0 & 0 & 0 \\
\hline 43 & $A M 1$ & French & 0.20 & 0 & 0 & 0 & 0 & 1 & 1 & 0 & 0 \\
\hline 44 & $A M 2$ & Russian & 0.20 & 0 & 0 & 0 & 0 & 0 & 1 & 0 & 0 \\
\hline 45 & AM3 & Arabic & 0.25 & 0 & 0 & 0 & 0 & 0 & 1 & 0 & 0 \\
\hline 46 & AM4 & Arabic & 0.25 & 0 & 0 & 0 & 0 & 0 & 1 & 0 & 0 \\
\hline 47 & AM5 & Arabic & 0.25 & 0 & 0 & 0 & 0 & 0 & 1 & 1 & 0 \\
\hline 48 & AM6 & Arabic & 0.25 & 1 & 0 & 1 & 0 & 0 & 0 & 0 & 0 \\
\hline 49 & $A M 7$ & French & 0.20 & 0 & 0 & 1 & 0 & 1 & 1 & 0 & 0 \\
\hline 50 & AM8 & Arabic & 0.25 & 0 & 0 & 1 & 0 & 0 & 0 & 0 & 1 \\
\hline 51 & AM9 & Arabic & 0.25 & 0 & 0 & 0 & 0 & 0 & 1 & 0 & 0 \\
\hline 52 & AM10 & Arabic & 0.25 & 1 & 1 & 0 & 1 & 0 & 1 & 0 & 1 \\
\hline
\end{tabular}




\begin{tabular}{|c|c|c|c|c|c|c|c|c|c|c|c|}
\hline$\dot{z}$ & $\begin{array}{l}\overrightarrow{\overrightarrow{0}} \\
\frac{\vec{v}}{\vec{D}} \\
\text { D }\end{array}$ & 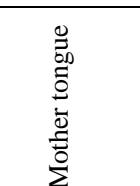 & 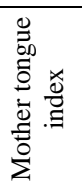 & 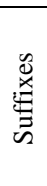 & 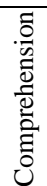 & $\begin{array}{l}0 \\
0 \\
0 \\
0 \\
0 \\
0 \\
0 \\
0\end{array}$ & $\begin{array}{l}\overrightarrow{0} \\
\dot{0} \\
3\end{array}$ & 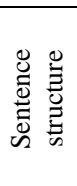 & 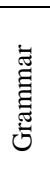 & $\begin{array}{l}\stackrel{b 0}{\Xi} \\
\text { 离 } \\
\text { ڤn }\end{array}$ & 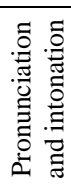 \\
\hline 53 & $A M 11$ & Arabic & 0.25 & 1 & 0 & 0 & 0 & 0 & 1 & 1 & 0 \\
\hline 54 & AM12 & Arabic & 0.25 & 0 & 1 & 0 & 0 & 0 & 1 & 0 & 0 \\
\hline 55 & AM13 & Arabic & 0.25 & 0 & 0 & 0 & 0 & 0 & 0 & 1 & 0 \\
\hline 56 & AM14 & Arabic & 0.25 & 0 & 0 & 1 & 0 & 0 & 1 & 0 & 0 \\
\hline 57 & AM15 & Arabic & 0.25 & 1 & 0 & 0 & 0 & 1 & 0 & 0 & 0 \\
\hline 58 & AM16 & Arabic & 0.25 & 0 & 0 & 0 & 0 & 0 & 1 & 1 & 0 \\
\hline 59 & AM17 & Arabic & 0.25 & 0 & 0 & 0 & 0 & 1 & 0 & 0 & 0 \\
\hline 60 & AM18 & Arabic & 0.25 & 0 & 0 & 0 & 0 & 1 & 1 & 0 & 0 \\
\hline 61 & AM19 & Arabic & 0.25 & 0 & 1 & 0 & 0 & 1 & 0 & 0 & 0 \\
\hline 62 & $A M 20$ & Senagalese & 0.50 & 0 & 0 & 1 & 0 & 0 & 0 & 1 & 0 \\
\hline 63 & AM21 & French & 0.20 & 1 & 0 & 0 & 0 & 1 & 1 & 0 & 0 \\
\hline 64 & AM22 & French & 0.20 & 0 & 0 & 0 & 0 & 0 & 1 & 0 & 0 \\
\hline 65 & AM23 & French & 0.20 & 1 & 0 & 1 & 0 & 0 & 0 & 0 & 1 \\
\hline 66 & AM24 & Arabic & 0.25 & 0 & 0 & 0 & 0 & 0 & 0 & 0 & 1 \\
\hline
\end{tabular}

\section{Conclusion}

According to the study's results, linguistic challenges encountered by French-speaking students when learning Turkish at the beginner level are, in order of prevalence, in the areas of "suffixes," "grammar", and "syntax." These results are in harmony with existing studies conducted on the topic (Akdoğan, 1993; Çotuksöken, 1983; Doğan, 1989; Gedik \& Gedikoğlu, 2015; Güven, 2007; Karabıyık \& Karazeybek, 2015; Kaya, 2010, 2011; Oğul, 2004; Özgür, 1992; Özkan, 1992; Şeylan, 2015; Tanış, 1988; Vandewalle, 2000; 2001). The linguistic challenges in question were put into a matrix along with student groups that were converted into numerical values based on the students' mother tongues, and an artificial neural network model was developed. With this modeling, the mother tongues of students belonging to the same family of languages, according to the etymon and structure of their respective languages, were sorted based on the resemblance of their etymon to Turkish. With this system, the student groups, converted into numerical values according to rules set via the use of artificial neural networks, could easily be matched to different or similar target values. Hence, it would be possible to foresee the challenging subjects that future students will face when they begin learning Turkish as a foreign language. In this way, the teaching staff will be able to pinpoint in advance the subjects they will need to focus on and to subsequently form custom study plans for students. They will also have the advantage of determining each student's weaknesses and strengths. In various studies (Musso \& Cascallar, 2009; Musso, Kyndt, Cascallar, \& Dochy, 2013), the artificial neural networks were used to estimate learners' academic performance, which enabled low academic performance to be identified and treated in the future.

Thus, it is also possible to obtain more in-depth results than those that have thus far been obtained based on the simple empirical observations by teachers of Turkish as a foreign language. Thanks to this approach, homogenous language classes can be composed. In addition, methods/approaches, teaching environments, and 
materials that match characteristics of students' mother tongues can be developed by considering the results of the study.

\section{Limitations and suggestions}

This study was conducted using the method of convenience sampling, with voluntary participation of 66 students from a body of 96 French-speaking students taking Turkish as an elective foreign language and enrolled in different language or literature-related undergraduate and graduate programs in universities in France. As such, this ratio presents a serious limitation to the generalization of the study's results. The generalizability of the study findings can be increased by conducting studies with students whose mother tongues belong to different families of languages in terms of their etymons. Another point is that the model developed in this research can be used in settings where Turkish is taught as a foreign language to see its effects on linguistic challenges encountered in mixed groups.

\section{Acknowledgments}

I would like to extend my gratitude to my valuable colleague, Asst. Prof. Fahri Vatansever, Faculty Member at Uludag University Faculty of Engineering, Department of Electrical-Electronic Engineering for his contributions to the development of the modeling in this study.

\section{References}

Akar, A. (2013). Türk dili tarihi [The history of Turkish language]. Ankara, Turkey: Ötüken Neşriyat.

Akdoğan, G. (1993). Yabancıların Türkçe öğreniminde ad durumu ve çekim açısından sık rastlanan yanlışlar ve nedenleri [The common errors in case endings and conjugation made by foreign students learning Turkish and the causes of the errors]. Master's thesis, Ankara University, Ankara, Turkey.

Akkaya, A., \& Gün, M. (2016). Araplara Türkçe öğretiminde karşılaşılan sorunlar: Ürdün örneği [Common problems in teaching Turkish to Arabs: Jordan sample]. Turkish Studies: International Periodical for the Languages, Literature and History of Turkish or Turkic, 11, 9-18. https://dx.doi.org/10.7827/TurkishStudies.11231

Arıcı, A. F., \& Kaldırım, A. (2015). 21. yüzyılda bir medeniyet ve bilim dili olarak Türkçe: sorunlar ve çözümler [Turkish language as a civilization and science language in the 21st century: Problems and solutions]. Erzincan Üniversitesi Sosyal Bilimler Enstitüsü Dergisi, 8, 269-284. Retrieved from https://docplayer.biz.tr/24705569-21-yuzyilda-bir-medeniyet-ve-bilim-dili-olarak-turkce-sorunlar-vecozumler.html

Arslan, M. (2012). Tarihi Süreçte Türkçenin yabancı dil olarak öğretimi-öğrenimi çalışmaları [A historical perspective on teaching and learning of Turkish as a foreign language]. Kahramanmaraş Sütçü İmam Üniversitesi Sosyal Bilimler Dergisi, 9, 167-188. 
Ataseven, B. (2013). Yapay sinir ağları ile öngörü modellemesi [Forecasting by using artificial neural networks]. Öneri Dergisi, 10, 101-115.

Ayaz, H., \& Akkaya, A. (2010). Yabancılara Türkçe öğretiminde karşılaşılan sorunlar üzerine bazı düşünceler [Some thoughts on challenges encountered in the teaching of Turkish to foreigners]. In N. E. Uzun, M. E. Gökmen, \& C. Kurt (Eds.), Yabancı dil olarak Türkçe öğretiminde yeni çalışmalar: 8. Dünyada Türkçe ögretimi sempozyumu bildirileri (pp. 214-218). Ankara, Turkey: TÖMER Yayınları.

Aydın, T. (2010). Arapça ve Türkçe'de sesler: Karşıtsal çözümleme [The letters in Arabic and Turkish: Constrastive analysis]. EKEV Akademi Dergisi, 14, 321-334.

Baccouche, T. (2009). Dynamique de la langue arabe [The dynamics of the Arabic language]. Synergies Tunusie, 1, 17-24.

Bakır, S. (2014). Türkiye'deki yabancılara Türkçe öğretim merkezleri ve Atatürk Üniversitesi Dil Eğitimi Uygulama ve Araştırma Merkezi [Turkish teaching centres to the foreigners in Turkey and Atatürk University Language Teaching Application and Research Centre]. Atatürk Üniversitesi Türkiyat Araştırmaları Enstitüsü Dergisi, 51, 435-456.

Biçer, N., Çoban, İ., \& Bakır, S. (2014). Türkçe öğrenen yabancı öğrencilerin karşılaştığı sorunlar: Atatürk Üniversitesi örneği [The problems faced by the foreign students learning Turkish: Atatürk University case]. Uluslararası Sosyal Araştırmalar Dergisi, 7, 125-135.

Brew, L. S. (2008). The role of student feedback in evaluating and revising a blended learning course. Internet and Higher Education, 11, 98-105. https://dx.doi.org/10.1016/j.iheduc.2008.06.002

Büyüköztürk, Ş., Çakmak, E. K., Akgün, Ö. E., Karadeniz, Ş., \& Demirel, F. (2012). Bilimsel araştırma yöntemleri [Scientific research methodologies]. Ankara, Turkey: PegemA.

Çiçek, M. (2010). Türkçenin yabancılara öğretiminde karşılaşılan sorunlar ve çözüm önerileri: Fransa örneği [Challenges encountered in the teaching of Turkish to foreigners and proposed solutions: The case of France]. In İ. H. Altınok \& Y. Yeniçerioğlu (Eds.), Yabancı dil olarak Türkçe öğretimi ve ögretmenliği çalıştayı kitabı (pp. 44-48). Ankara: Promeda Yayınları.

Çotuksöken, Y. (1983). Yabancıların Türkçe öğrenirken karşılaştıkları güçlükler ve yaptıkları yanlışlıklar [The difficulties faced and mistakes made by foreigners while learning Turkish]. Türk Dili Dil Öğretimi Özel Saylsl, 379-380, 88-94.

Creswell, J. W. (2014). A concise introduction to mixed methods research. Thousand Oaks, CA: Sage.

Dede, M. (1983). Yabancı dil öğretiminde karşılaştırmalı dilbilim ve yanlış çözümlemesinin yeri [The place of comparative linguistics and error analysis in foreign language teaching]. Türk Dili Dil Öğretimi Özel Saylsl, 47, 123-135.

De l'Europe, Conseil (Ed.). (2000). Un cadre européen commun de référence pour les langues [The common European framework of reference for languages (CEFR)]. Strasbourg, France: Division des politiques linguistiques.

Doğan, A. (1989). Yabancıların Türkçeyi öğrenirken karşılaştıkları güçlükler ve yaptıkları bazı hatalar. [The difficulties faced and some mistakes made by foreigners while learning Turkish] Hacettepe Üniversitesi Edebiyat Fakültesi Dergisi, 6, 259-261. 
Dolunay, S. K. (2005). Türkiye ve dünyadaki Türkçe öğretim merkezleri ve Türkoloji bölümleri üzerinde bir değerlendirme [A review on Turkish teaching centers and Turcology departments in Turkey and around the world]. XIV. Ulusal eğitim bilimleri kongresi bildirileri (pp. 1-7).

Durmuş, M. (2013). Türkçenin yabancılara öğretimi sorunlar, çözüm önerileri ve yabancilara Türkçe öğretiminin geleceğiyle ilgili görüşler [Teaching Turkish to foreigners: Problems, solutions and ideas on the future of teaching Turkish to foreigners]. Adlyaman Üniversitesi Sosyal Bilimler Enstitüsü Dergisi, 6 , 207-228. https://dx.doi.org/10.14520/adyusbd.488

Ercilasun, A. B. (2011). Başlangıçtan yirminci yüzyıla Türk dili tarihi [History of Turkish language from the beginning to the twentieth century]. Ankara, Turkey: Akçağ Yayınları.

Erdem, İ. (2009).Yabancılara Türkçe öğretimiyle ilgili bir kaynakça denemesi [A bibliography essay on the teaching Turkish to the foreigners]. Turkish Studies: International Periodical for the Languages, Literature and History of Turkish or Turkic, 4, 888-937. https://dx.doi.org/10.7827/TurkishStudies.709

Gedik, S., \& Gedikoğlu, F. (2015). Yabancilara Türkçe öğretiminde +dan hal ekinin öğreniminde ve öğretilmesinde karşılaşılan güçlükler [The difficulties encountered in teaching, education of "+dan" state adding, being instructed to the foreigner]. International Journal of Languages' Education and Teaching, UDES-2015, 2356-2368.

Göçer, A., Çaylı, C., \& Çavuş, S. (2016). Türkçenin yabancı dil olarak öğretimiyle ilgili kaynakça denemelerine kesitsel bir katk1: 2013-2015 yılları [A sectional contribution on trials of bibliography in relation to teaching Turkish as a foreign language: 2013-2015 years]. Uluslararası Türkçe Eğitimi ve Öğretimi Dergisi: Kuram ve Uygulama, 1, 86-109.

Göçer, A., \& Moğul, S. (2011). Türkçenin yabancı dil olarak öğretimi ile ilgili çalışmalara genel bir bakış [A general perspective on the studies in accordance with the teaching Turkish as a foreign language]. Turkish Studies: International Periodical for the Languages, Literature and History of Turkish or Turkic, 6, 797810. https://dx.doi.org/10.7827/TurkishStudies.2470

Göçer, A., Tabak, G., \& Coşkun, A. (2012). Türkçenin yabancı dil olarak öğretimi kaynakçası [A bibliography of teaching Turkish as a foreign language]. Türklük Bilimi Araştırmaları, 32, 73-126.

Güler, E. B., \& Eyüp, B. (2016). Hâl eklerinin ikinci dil olarak Türkçe öğrenen öğrenciler tarafindan kullanılmas1 [The use of case suffixes by students who learn Turkish as a second language]. Turkish Studies: International Periodical for the Languages, Literature and History of Turkish or Turkic, 11, 295-312. https://dx.doi.org/10.7827/TurkishStudies.9902

Güven, E. (2007). Yabancıların Türkçe öğrenirken ad durum eklerinde yaptıkları hataların çözümlenmesi ve bu hataların giderilmesine yönelik öneriler [A study on the analysis of the errors by foreigners in learning Turkish regarding nominal case suffixes and some suggestions to eliminate these errors]. Master's thesis, Dokuz Eylül University, İzmir, Turkey.

Güzel, A., \& Barın, E. (2013). Yabancı dil olarak Türkçe ögrretimi [The teaching of Turkish as a foreign language]. Ankara, Turkey: Akçağ yayınları.

Hsu, K., Gupta, H. V., \& Sorooshian, S. (1995). Artificial neural network modeling of the rainfall-runoff process. Water Resources Research, 31, 2517-2530. https://dx.doi.org/10.1029/95WR01955 
Irmak, Y. (2016). Belçika’da Türkçe öğretiminin sorunları ve Türkçe ve Türk kültürü ders kitaplarına eleştirel bir yaklaşım [Teaching in Belgium and critical approach for Turkish and Turkish culture books]. Bingöl Üniversitesi Sosyal Bilimler Enstitüsü Dergisi, 6, 301-312.

Jean, G. (1987). L'écriture, mémoire des hommes [Writing: The story of alphabets and scripts]. Paris, France: Gallimard.

Kahriman, R., Dağtaş, A., Çapoğlu, E., \& Ateşal, Z. (2013). Yabancılara Türkçe öğretimi kaynakçası [Bibliography of teaching Turkish language to foreign people]. Dil, Edebiyat ve Halkbilimi Araştırmaları Dergisi, 1, 80-132. http://dx.doi.org/10.12992/TURUK15

Kapusuzoğlu, R. (2010). Dil ve anlatım-4: Dünya dillerinin sinıflandırılması [Language and expression 4: The classification of the world's languages].

Karabıyık, E., \& Karazeybek, A. (2015). Türkiye'de ve yurtdışında A1 düzeyinde Türkçe öğrenen öğrencilerin dil yanlışlıklarının karşılaştırılması [The comparison of language errors made by A1 level students learning Turkish in Turkey and abroad]. In I. Uluslararası dil eğitimi ve öğretimi sempozyumu bildiri özetleri kitabı (p. 164). Ankara, Turkey: Pegem Akademi.

Karataş Demirtaş, S., \& Karataş Acer, E. (2016). Türkçe öğretiminde karşılaşılan sorunlara yönelik bir değerlendirme: Passau Üniversitesi örneği [An assessment of challenges encountered in the teaching of Turkish: The case of Passau University]. In A. Okur, B. İnce, \& İ. Güleç (Eds.), Yabancllara Türkçe ögretimi üzerine araştırmalar (pp. 177-184). Sakarya, Turkey: Sakarya Üniversitesi TÖMER.

Kaya, C. (2010). Türkçede kelime çekiminde tabanın değişmesi ve Türkçenin öğretiminde yarattığı sorunlar. [The change of the base and problems in word conjugation in Turkish teaching]. In N. E. Uzun, M. E. Gökmen, \& C. Kurt (Eds.), Yabancı dil olarak Türkçe öğretiminde yeni çalı̧̧malar: 8. Dünyada Türkçe ögretimi sempozyumu bildirileri (pp. 199-201). Ankara, Turkey: TÖMER Yayınları.

Kaya, C. (2011, May). Türkçenin yabancı dil olarak öğretiminde gramer sırası sorunu. [The problem of word order in teaching Turkish as a foreign language]. Paper presented at the 9. Uluslararası Dünyada Türkçe Öğretimi: Çağdaş Türk Yazı Dillerinin Öğretimi Sempozyumu, Bişkek, Kazakistan.

Kongar, E. (2002, April 01st). Üçüncü küreselleşme ne getirecek? [What will the third globalisation bring? Cumhuriyet.

Kuşçu, S. (2013). Türkçenin yabancı dil olarak öğretiminde öğretmen bilişi ve öğrenci inanışları [Teacher’s cognition and student beliefs in the teaching of Turkish as a foreign language]. Master's thesis, Ankara University, Ankara, Turkey.

Kutlu, B., \& Badur, B. (2009). Yapay sinir ağları ile borsa endeksi tahmini [Stock market index prediction with artificial neural networks]. Yönetim, 20, 25-40.

Miles, M. B., \& Huberman, M. A. (1994). Qualitative data analysis: An expanded sourcebook ( ${ }^{\text {nd }}$ ed.). Thousand Oaks, CA: Sage Publications.

Musso, M. F., \& Cascallar, E. C. (2009). New approaches for improved quality in educational assessments: Using automated predictive systems in reading and mathematics. Journal of Problems of Education in the 21st Century, 17, 134-151. http://oaji.net/articles/2014/457-1399915068.pdf

Musso, M. F., Kyndt, E., Cascallar, E. S., \& Dochy, F. (2013). Predicting general academic performance and identifying the differential contribution of participating variables using artificial neural networks. Frontline Learning Research, 1, 42-31. https://dx.doi.org/10.14786/flr.v1i1.13 
Nurlu, M., \& Özkan, N. (2016). Türkiye Türkçesi öğrenen Türkmenlerde görülen sesli okuma yanlışları ve çözüm önerileri [Oral reading mistakes seen in Turkmen people who are learning Turkey Turkish and suggestions for solutions]. Mustafa Kemal Üniversitesi Sosyal Bilimler Enstitüsü Dergisi, 13, 24-37.

Oğul, E. (2004). Yabancıların Türkçeyi ögrrenirken yaptıkları yanlışlar [The language mistakes made by the learners of Turkish as a foreign language]. Master's thesis, Yildiz Technical University, İstanbul, Turkey.

Ozdemir, C. B. (2004, April). INALCO, Paris'te Türkçe öğretimi, tarihçe, sorunlar ve çözüm arayışları [INALCO, Teaching, history, problems and solutions of Turkish in Paris]. Paper presented at the VI. Dünyada Türkçe Öğretimi Sempozyumu, Ankara, Turkey.

Özgür, A. (1992). Anadili İngilizce olan öğrencilerde Türkçenin sözdizimine ilişkin olumsuz aktarım yanlşsları [Negative transfer mistakes of native English learners related to Turkish syntax]. Master's thesis, Ankara University, Ankara, Turkey.

Özkan, A. (1992). Yabancıların Türkçeyi öğrenmeleri esnasinda yaptıklart isim hâl ekleri yanlışlarl ve bu konunun değerlendirilmesi [Affix errors made by foreigners while learning Turkish and its evaluation]. Master's thesis, Gazi University, Ankara, Turkey.

Özyürek, R. (2009). Türk devlet ve topluluklarından gelen Türk soylu yabancı öğrencilerin türkçe öğreniminde karşılaştığı problemler [The problems encountered in learning Turkish by foreign students of Turkic origin coming from Turkic states and communities to Turkish unıversities]. Turkish Studies: International Periodical for the Languages, Literature and History of Turkish or Turkic, 4, 1819-1861. https://dx.doi.org/10.7827/TurkishStudies.759

Pavlin-Bernardić, N., Ravić, S., \& Matić, I. P. (2016). The application of artificial neural networks in predicting children's giftedness. Suvremena Psihologija, 19, 49-58. https://dx.doi.org/10.21465/2016-SP191-04

Philip-Asdih, C. (1997). Choix linguistiques des familles culturellement mixtes: les cas des familles francomaghrébines [Language choices of culturally mixed families: The cases of Franco-Maghreb families]. In M. L. Lefebvre \& M. A. Hily (Eds.), Les situations plurilingues et leurs enjeux (pp. 35-45). Paris, France: L'Harmattan.

Puren, C. (1988). Histoire des méthodologies de l'enseignement des langues [History of the methodology of the teaching of languages]. Paris, France: Nathan/CLE International.

Ravel, M. (2013). Les familles de langues.

Şeylan, A. (2015). Yabancı dil olarak Türkçe öğretiminde fiil çekimi ve fiil çekimlerindeki düzensizlikler [Verb conjugation and irregularities in verb conjugation in Teaching Turkish as a foreign language]. International Journal of Languages' Education and Teaching, UDES-2015, 110-124.

Tanış, A. (1988). Türkçenin İtalyanlara öğretiminde karşılaşılan zorluklar-kolaylıklar [The difficulties and eases faced while teaching Turkish to Italians]. Dil Dergisi, 1, 101-107.

Üstünel, E., \& Aydın, S. (2009). A comparative study on teaching Turkish and English as a foreign language at the post graduate level. Procedia-Social and Behavioral Sciences, 1, 259-264.

https://dx.doi.org/10.1016/j.sbspro.2009.01.047

Vandewalle, J. (2000). Batı dillerini konuşan öğrencilerin Türkçedeki eylemlerde karşılaştıkları bazı güçlükler [Some problems concerning the Turkish verb encountered by students speaking Western languages]. Dil Dergisi, 94, 23-29. 
Vandewalle, J. (2001). Batı dillerini konuşan öğrencilerin Türkçede arayıp da bulamadıkları bir yapı üzerine. [On the basis of a structure that the students of Western languages are not able to find in Turkish.] In TÖMER (Ed.), IV. Uluslararası Dünyada Türkçe öğretimi sempozyumu bildirileri (pp. 72-86). Ankara, Turkey: Ankara Üniversitesi Basımevi.

Vatansever, F., \& Doğalı, G. (2011). Klasik enterpolasyon yöntemleri ve yapay sinir ağı yaklaşımlarının karşılaştırılması [Comparison of classical interpolation methods and artificial neural network approaches]. In Proceedings of 6th International Advanced Technologies Symposium (pp. 51-54). Elazığ, Turkey.

Xu, W., \& Rudnicky, A. (2000). Can artificial neural networks learn language models? In 6th International Conference on Spoken Language Processing (pp. 202-205). Beijing, China: ISCA.

Yıldırım, A., \& Şimşek, H. (2011). Sosyal bilimlerde nitel araştırma yöntemleri [Qualitative research methods in social sciences]. Ankara, Turkey: Seçkin Yayıncılık.

Yıldız, C., \& Çakır, M. (2016). Almanya'daki Türk öğretmenlerin bu ülkede verdikleri Türkçe ve Türk kültürü dersinin uygulanmasına ilişkin görüşleri ve karşıllaştıkları sorunlar [Opinions and challenges of Turkish teachers on the application of Turkish language and culture lessons in Germany]. In A. Okur, B. İnce, \& İ. Güleç (Eds.), Yabancılara Türkçe öğretimi üzerine araştırmalar (pp. 27-36). Sakarya, Turkey: Sakarya Üniversitesi TÖMER. 